\title{
EFFECT OF SOME SOIL AMENDMENTS ON YIELD AND DISEASE INCIDENCE IN PEANUT (ARACHIS HYPOGAEA L)
}

\section{ISMAIL, F. M. ${ }^{1}$ AND S. M. ABD EL-MOMEN ${ }^{2}$}

1. Field Crops Research Institute, ARC, Giza, Egypt

2. Plant Pathology Research Institute ARC, Giza, Egypt

(Manuscript received 29 June 2006)

(Manuscript received 29 June 2006)
Abstract
Greenhouse and field experiments were carried out in sandy
soil at the Ismailia Agricultural Experiment Research Station to
determine the effect of five soil amendments on the yield and
disease incidence in two peanut cultivars (Gregory and Giza 6).
The results indicated that the Gregory cultivar significantly
surpassed Giza 6 regarding plant growth parameters, yield and
yield components. It was also less susceptible to pre- and post-
emergence damping-off and nematode infection in two testing
seasons. Adding gypsum increased plant height, number of
branches/plant, 100 -seed weight, shelling percentage, pod weight
and oil yield followed by farmyard manure and wheat straw for
most of these characters.
Fusarium spp., Macrophomina phaseolina, Rhizoctonia solani,
Sclerotium rolfsii, Aspergillus spp., Pythium spp. and Meloidogyne
spp. were isolated from peanut cultivated at the Ismailia Agric Res.
Station. Amending soil with gypsum gave the highest reduction of
$F$. solani, M. phaseolina, $R$. solani and S. rolfsii incidence, damped-
off seedlings and rotted pods in the greenhouse. Also, gypsum
was the most effective treatment in the field experiments reducing
the pre-, post-emergence damping-off, pod rots and nematode
infections in both cultivars in the two seasons. There was a
significant interaction between peanut cultivars and treatments in
six out of eleven studied characters in their combined data.
Key words: soil amendments, peanut, damping-off, pod rots

INTRODUCTOIN

Peanut (Arachis hypogaea L.) is an important oil crop in many parts of the world including Egypt where its cultivation is concentrated (80-85\%) in the newly reclaimed sandy soils (Omar, 1988). Seeds are used for human consumption as nuts and for exportation, where about $35-40 \%$ of the national production is usually exported. Most of the peanut cultivation is in soils low in fertility and usually infested with several plant pathogens. Plant nutrition is crucial in those soils for acceptable and exportable peanut yield. Peanut is affected by several soil-borne diseases caused by Fusarium spp, Rhizoctonia solani, Macrophomina phaseolina, Sclerotium rolfsii, Pythium spp., Aspergillus spp. and Meloidogyne spp. (Helal et al., 1994). Pesticides have been, for a long time, the major control strategy to peanut diseases. Induction of resistance to those pathogens, the use of biocontrol agents and organic fertilization were investigated. Supplying sandy soils with some crop by-products such as wheat straw helps in keeping soil moisture and consequently increases the seed germination. It 
was reported that peanut planted after clover or barley showed a significant increase in yield and other components. The yield of peanut after barley or wheat surpassed those after clover or faba bean (Greish and Behairy, 2003).

Manuring plays a favorable role in improving physical and biological properties of soil, increasing nutrients availability and productivity of peanut (Ahmed and Osman, 2003). It was reported that application of $500 \mathrm{~kg}$ gypsum/ fed increased pod yield/fed and improved yield quality (Hussein et al., 2000).

Addition of sulphur had significantly increased the 100-seed weight and pod yield of peanut grown in sandy soil. Adding $\mathrm{N}$ up to $30 \mathrm{~kg} \mathrm{~N} /$ fed and $\mathrm{P}$ up to $46.5 \mathrm{~kg}$ $\mathrm{P}_{2} \mathrm{O}_{5} /$ fed, $\mathrm{K}$ up to $48 \mathrm{~kg} \mathrm{~K} \mathrm{O} /$ fed and $\mathrm{P}$ up to $31 \mathrm{~kg} \mathrm{P}_{2} \mathrm{O}_{5} /$ fed increased peanut growth, yield and quality. Amending soil with gypsum and wheat straw before planting greatly reduced infection with damping-off, pod rot and increased yield more than sulphur, farmyard manure or mineral fertilizers (Chen and Hung, 1992). Nematodes are serious problem in the production of many crops in Egypt including peanut. Control of nematodes in peanut has been achieved, mainly, by nematicides. The addition of some soil amendments improved soil characteristics and increased the availability of some nutritive elements which, consequently, affect plant growth and yield as well as the resistance or tolerance of plants against several pathogens (Akhtar et al., 1998).

The aim of this investigation was to determine the effect of some soil amendments on peanut yield, its components, quality and infection by damping-off, pod rots and root knot nematode under conditions of the Ismailia Agricultural Research Station.

\section{MATERIALS AND METHODS}

Isolation and identification of the causal organisms:

Peanut seeds, seedlings, plants and pods, showing disease symptoms, were collected from peanut fields at the Ismailia Agricultural Research Station. Isolation was carried out on Potato Dextrose Agar (PDA) and fungal isolates were purified using the hyphal tip technique. Identification based on morphological characteristics of the isolated fungi was made according to Barnett and Hunter (1972).

Preparation of the fungal inocula:

Each of the isolated Fusarium solani, Phizoctonia solani, Macrophomina phaseolina and Sclerotium rolfsii was grown in $500 \mathrm{ml}$ conical flasks containing $200 \mathrm{ml}$. of potato dextrose broth and incubated at $26^{\circ} \mathrm{C}$ for 10 days. The medium was decanted and each fungal mat was mixed with a suitable volume of distilled water and mixed thoroughly for 30-40 seconds in a blender. The concentration of each fungal propagules (mycelial fragments and spores) was adjusted to $10^{10} / \mathrm{ml}$ with the aid of a haemocytometer. 
Effect of five soil amendments on some peanut diseases in the greenhouse:

Effect of gypsum, wheat straw, farmyard manure, sulphur and mineral fertilization on pre- and post-emergence damping-off, pod rots and yield was tested in the greenhouse. Seeds of Gregory and Giza 6 cultivars were planted in $30 \mathrm{~cm}$ pots filled with autoclaved sandy soil ( $4.5 \mathrm{~kg}$ ). Any of gypsum, $10 \mathrm{gm}$, wheat straw, $10 \mathrm{gm}$, farmyard manure, $150 \mathrm{gm}$ or NPK (ammonium nitrate, 2gm, calcium super- phosphate, $5 \mathrm{gm}$ and potassium sulphate, $3 \mathrm{gm}$ ) was incorporated, separately, with soil in the pot. Inocula of the aforementioned fungi $\left(10^{10}\right.$ fungal spores or propagules/ $\mathrm{ml}$ ) were added to each pot at $20 \mathrm{ml} /$ pot 7 days after adding the soil amendments. Four seeds were sown in each pot, four pots were used as replicates for each treatment and four pots were filled with non-amended soil to serve as control. Percentages of pre- and post-emergence damping-off were recorded 30 and 60 days after sowing, while pod rots and the average pod yield/ plant were determined at harvest. The average pod yield/ plant was estimated as the total pod yield of a pot divided by the number of survived plants in that pot.

Field experiments: Two field experiments were conducted at Ismailia Agric. Res. Station, to determine the effect of five soil amendments on yield, its components and quality and the incidence of pre-, post-emergence damping-off, pod rots and root-knot nematode infections of Giza- 6 and Gregory peanut cultivars. The amendments in used were as follows:

1- Mineral fertilizers (NPK) of calcium super phosphate $\left(15 \% \mathrm{P}_{2} \mathrm{O}_{5}\right)$, potassium sulphate $(48 \% \mathrm{~K} 20)$ at 200 and $50 \mathrm{~kg} /$ fed, respectively, were added during soil preparation and ammonium nitrate $(33 \% \mathrm{~N})$ at $150 \mathrm{~kg} / \mathrm{fed}$ as three equal doses during soil preparation, 21 and 30 days from sowing.

2- Wheat straw at one ton/ fed was mixed with the soil by a shallow hoeing 30 days before sowing.

3- Farmyard manure at $30 \mathrm{~m}^{3}$ was added during soil preparation.

4- Gypsum at one ton/ fed in two equal portions during soil preparation and drenching at beginning of the flowering stage.

5- Sulphur at $500 \mathrm{~kg} /$ fed was added during soil preparation.

The mechanical and chemical analyses of the used soil (the upper $30 \mathrm{~cm}$ ) were conducted at the Soils and Water Res. Lab. at Ismailia Agric. Res. Station, and shown in Table (1). The analysis of wheat straw and farm manure is in Table (2). 
Table 1. Mechanical and chemical analysis of the soil before conducting the experiments.

\begin{tabular}{|lll|ll|}
\hline \multicolumn{2}{|l|}{ Mechanical analysis } & \multicolumn{2}{l|}{ Chemical analysis } \\
\hline \multicolumn{2}{|l|}{ Coarse sand \% } & 71.86 & $\mathrm{pH}(1-2.5$ soil : water suspension) & 7.9 \\
Fine sand $\%$ & 22.11 & $\mathrm{EC}\left(\right.$ mohms $/ \mathrm{cm}^{-1}(1: 5$ water extract) & 0.318 \\
Silt & $\%$ & 3.82 & $\mathrm{OM} \%$ & 0.350 \\
Clay & $\%$ & 2.21 & Available $\mathrm{N}(\mathrm{ppm})$ & 12.115 \\
& & Available $\mathrm{P}(\mathrm{ppm})$ & 1.921 \\
Soil texture & sandy & Available $\mathrm{K}(\mathrm{ppm})$ & 56.715 \\
\hline
\end{tabular}

The treatments involved two peanut cultivars and five soil amendments in addition to the non-treated control ( 2 peanut cvs $X(5$ amendments + control $)=12$ treatments).

The experiments were laid out in a split- plot design (Snedecor and Cochran, 1967) in four replicates for each treatment. In the main plots, the two cultivars were randomly distributed, while the five soil amendments + the control were randomly allotted in sub- plots. The area of each sub- plot was $9 \mathrm{~m}^{2}$ ( $3 \times 3 \mathrm{~m}$ ) and consisted of five rows $3 \mathrm{~m}$ long and $60 \mathrm{~cm}$ apart with hill spacing at $10 \mathrm{~cm}$. The preceding crop was wheat in both seasons. Seeds of peanut were sown on $23^{\text {rd }}$ and $26^{\text {th }}$ of May in 2003 and 2004, respectively.

Weed control was made by a herbicide and hand hoeing. Irrigation was applied every two days using sprinkler irrigation system. Other agricultural practices for peanut production were applied according to the recommendations.

\section{2-The recorded readings:}

A- Agronomic characters: At harvest, ten guarded plants were taken randomly from the inner rows of each plot in both seasons to measure the following characters:

\section{1- Plant growth parameters:}

1- Plant height (cm). 2- Number of branches/plant. 3- Number of pods/plant. 4- Pods weight/plant (gm). 5- Seed weight/plant (gm). 6- Weight of 100 pods (gm).

7- Weight of 100-seed (gm).

8- Shelling percentage $\frac{\text { (weight of seeds/plant }(\mathrm{gm}))}{\text { (weight of pods/plant }(\mathrm{gm}))} \times 100$

2- Yield:

1- Pod yield/fed: All plants of the three inner rows $(1.8 \times 3 \mathrm{~m}=1 / 777.777 \mathrm{feddan})$

were harvested to estimate the pod weight in $\mathrm{kg} / \mathrm{m}^{2}$, then it was extrapolated to estimate pod yield $(\mathrm{kg} / \mathrm{fed})$. 
Table 2. Chemical analysis of wheat straw and farmyard manure used in this study.

\begin{tabular}{|c|c|c|c|c|}
\hline \multicolumn{2}{|c|}{ Wheat straw } & \multicolumn{3}{|c|}{ Farmyard manure } \\
\hline Chemical composition: & $\%$ & \multicolumn{3}{|c|}{ Chemical composition: } \\
\hline Moisture & 10.45 & \multicolumn{3}{|c|}{ A-Micronutrients (ppm) } \\
\hline Dry mater (DM) & 89.55 & Cu 12.50 & $\mathrm{Zn}$ & 5.60 \\
\hline Organic mater (OM) & 85.34 & Mn 56.00 & $\mathrm{Fe}$ & 50.82 \\
\hline Crude protein (CP) & 2.83 & \multicolumn{3}{|c|}{ B-Macronutrients (ppm) } \\
\hline Crude fiber (CF) & 39.21 & $\mathrm{~N} \quad 2.21$ & $\mathrm{P}$ & 0.53 \\
\hline Ether extract (EE) & 1.20 & K $\quad 0.45$ & & \\
\hline Nitrogen free extract (NFE) & 42.10 & \multicolumn{3}{|c|}{ C-Chemical analysis $(1: 5)$} \\
\hline Ash. & 14.66 & 3.25 & $\mathrm{Mg}$ & 8.0 \\
\hline & & $\mathrm{HCO}_{3} \quad 1.0$ & $\mathrm{Na}$ & 14.2 \\
\hline & & Cl 16.4 & $\mathrm{~K}$ & 1.9 \\
\hline & & $\mathrm{SO}_{4} \quad 15.9$ & $\mathrm{Ca}$ & 9.2 \\
\hline
\end{tabular}

2- Seed yield/fed: estimated by multiplying pod yield $(\mathrm{kg} / \mathrm{fed})$ by shelling percentage.

\section{3- Quality characters:}

1-Seed oil percentage: Dried mature seeds were ground to a fine powder to determine oil content using Soxhelt methods with diethyl ether as a solvent (A.O.A.C., 1980)

2-Oil yield (kg/fed): estimated as seed oil percentage $X$ seed yield $(\mathrm{kg} / \mathrm{fed})$.

B- Pathological measurements:

1- Damping-off: The percentages of pre- and post-emergence damping-off were determined 30 and 60 days after sowing by checking each plot, counting the infected seedlings and plants and correlating them to the total plant number/ plot.

2- Pod rots: At harvest, pods of ten plants, taken randomly from each plot, were collected, examined carefully and percentage of rotted pods was calculated.

3- Nematode infection: Ten peanut plants were taken randomly from each plot. Roots of each plant were washed by tap water and examined for nematode galling. The number of nematode galls/ plant was recoded as the mean number obtained from examining ten plants selected from each plot.

4- Other measurements: Plant height, pod yield and oil content were determined at harvest, as described before, to be correlated with infection by the target pathogens. 
C- Statistical analysis: The collected data were statistically analyzed as described by Snedecor and Cochran (1967). The new least significant difference was used to compare the differences among means (Waller and Duncan, 1969). Also, simple correlation coefficients ( $r$ ) among the studied characters were computed.

\section{RESULTS AND DISCUSSION}

\section{Agronomic characters:}

Results of both cultivars in response to soil amendments in two seasons and combined data indicated highly significant differences for plant height, number of branches/plant, number of pods/plant and pod weight/plant. This could be due to the genetic variability among cultivars and their utilization of various amendments added to the soil (Table 3). The introduced cultivar Gregory surpasses the local Giza 6 in the studied characters. Adding gypsum gave the tallest plants and the highest number of branches, number of pods/ plant and pod weight/ plant revealing its importance in the newly reclaimed soils. The control treatment gave the lowest values for the studied characters reflecting the poverty of this soil in various nutrients. It could be noted that values of the four characters were higher in $2^{\text {nd }}$ season than in the $1^{\text {st }}$ one. This was true for cultivars, various nutrient uptakes, added amendments and environmental fiuctuations. These results are in agreement with those of Hussein et al. (2000).

Table 3. Some agronomic characters as affected by cultivars and various soil amendments in 2003 and 2004 and their combination.

\begin{tabular}{|c|c|c|c|c|c|c|c|c|c|c|c|c|}
\hline \multirow{2}{*}{ Treatments } & \multicolumn{3}{|c|}{ Plant height $(\mathrm{cm})$} & \multicolumn{3}{|c|}{$\begin{array}{l}\text { No. of branches/ } \\
\text { plant }\end{array}$} & \multicolumn{3}{|c|}{ No. of pods/ plant } & \multicolumn{3}{|c|}{$\begin{array}{l}\text { Pod weight/ plant } \\
\text { (gm) }\end{array}$} \\
\hline & 2003 & 2004 & Comb. & 2003 & 2004 & Comb. & 2003 & 2004 & Comb. & 2003 & 2004 & Comb. \\
\hline \multicolumn{13}{|l|}{ Cultivars (v): } \\
\hline 1- Gregory (v1) & 24.7 & 26.2 & 25.6 & 6.0 & 6.6 & 6.3 & 30.6 & 29.5 & 30.0 & 42.3 & 42.4 & 42.3 \\
\hline 2- Giza 6 (v2) & 22.1 & 23.0 & 22.5 & 5.0 & 5.0 & 5.0 & 26.4 & 25.3 & 25.9 & 34.1 & 33.3 & 33.7 \\
\hline F-test & ** & ** & $* *$ & ** & $* *$ & ** & * & ** & ** & ** & ** & ** \\
\hline soil amendments (s): & & & & & & & & & & & & \\
\hline 1- Wheat straw & $23.7^{\mathrm{a}}$ & $25.6^{\mathrm{a}}$ & $24.6^{a}$ & $6.3^{a}$ & $6.3^{b}$ & $6.3^{\mathrm{a}}$ & $30.0^{a}$ & $29.8^{\mathrm{a}}$ & $29.9^{a}$ & $39.8^{\mathrm{b}}$ & $40.2^{\mathrm{a}}$ & $40.0^{a}$ \\
\hline 2- Farmyard manure & $24.4^{\mathrm{a}}$ & $26.2^{\mathrm{a}}$ & $25.3^{a}$ & $6.3^{a}$ & $7.0^{\mathrm{a}}$ & $6.6^{\mathrm{a}}$ & $31.4^{a}$ & $29.6^{\mathrm{a}}$ & $30.5^{\mathrm{a}}$ & $41.7^{\mathrm{a}}$ & $40.9^{a}$ & $41.3^{a}$ \\
\hline 3-Gypsum & $25.4^{\mathrm{a}}$ & $26.0^{\circ}$ & $25.7^{a}$ & $6.4^{a}$ & $7.0^{\mathrm{a}}$ & $6.7^{\mathrm{a}}$ & $33.1^{\mathrm{a}}$ & $31.1^{\mathrm{a}}$ & $32.1^{\mathrm{a}}$ & $45.0^{\mathrm{a}}$ & $43.4^{\mathrm{a}}$ & $44.2^{2}$ \\
\hline 4- Sulphur & $24.2^{\mathrm{a}}$ & $25.0^{\mathrm{a}}$ & $24.6^{\mathrm{a}}$ & $5.6^{b}$ & $5.2^{\mathrm{d}}$ & $5.4^{\mathrm{b}}$ & $29.0^{\mathrm{a}}$ & $27.9^{\mathrm{a}}$ & $28.4^{\mathrm{a}}$ & $38.6^{\mathrm{b}}$ & $38.8^{\mathrm{b}}$ & $38.7^{\circ}$ \\
\hline 5- Mineral (NPK) & $23.5^{\mathrm{a}}$ & $25.3^{\mathrm{a}}$ & $24.4^{a}$ & $4.8^{c}$ & $5.8^{\mathrm{c}}$ & $5.3^{\circ}$ & $28.1^{\mathrm{a}}$ & $27.0^{\mathrm{a}}$ & $27.5^{\circ}$ & $37.8^{\mathrm{b}}$ & $37.8^{\mathrm{b}}$ & $37.8^{\mathrm{b}}$ \\
\hline 6- control & $19.1^{b}$ & $20.2^{\mathrm{b}}$ & $19.7^{b}$ & $3.5^{d}$ & $3.4^{\mathrm{e}}$ & $3.5^{c}$ & $19.4^{\mathrm{b}}$ & $19.1^{\mathrm{b}}$ & $19.2^{\mathrm{b}}$ & $26.3^{c}$ & $25.0^{6}$ & $26.1^{c}$ \\
\hline$F$ - test & ** & ** & ** & ** & ** & ** & ** & ** & ** & ** & ** & *** \\
\hline Interaction (v.s) & N.S & N.S & N.S & N.S & ** & ** & N.S & N.S & N.S & N.S & N.S & ** \\
\hline
\end{tabular}

(*Significant - ** Highly significant - Means having the same letter do not differ significantly)

The interaction between cultivars and various amendments was, in general, insignificant showing that each factor acted independently for plant height, No. of branches/ plant, No. of pods/plant and pod weight/plant. Data of mean values of seed weight/plant, 100-pod weight, 100-seed weight and shelling $\%$ as affected by 
cultivars and soil amendments and interaction effect between them in 2003 and 2004 seasons and combined data are shown in Table (4).

The statistical analysis indicated significant variations between cultivars in both seasons and in the combined data. Also, significant differences were detected among various soil amendments for seed weight/plant, 100-pod weight and 100-seed weight except for shelling $\%$ in the $1^{\text {st }}$ and $2^{\text {nd }}$ seasons and the combined data.

The Gregory cultivar gave higher seed weight/plant, 100-pod weight, 100-seed weight and shelling\% than Giza 6 , indicating that this cultivar could be cultivated successfully in this area. Also, gypsum addition gave the highest seed weight/plant, 100 -pod weight, 100 -seed weight and shelling $\%$ in both seasons and combined data .

Meanwhile, control treatment gave the lowest values for the studied characters, reflecting the poverty of this soil in various nutrient elements. These results are in accordance to those obtained by Ahmed and Osman (2003).

Table 4. Yield components as affected by cultivars and various amendments in 2003 and 2004 and their combined data.

\begin{tabular}{|c|c|c|c|c|c|c|c|c|c|c|c|c|}
\hline \multirow[b]{2}{*}{ Treatments } & \multicolumn{3}{|c|}{$\begin{array}{l}\text { Seed weight/plant } \\
\text { (gm) }\end{array}$} & \multicolumn{3}{|c|}{ 100- pod weight (gm) } & \multicolumn{3}{|c|}{$\begin{array}{c}\text { 100-seed weight } \\
(\mathrm{gm})\end{array}$} & \multicolumn{3}{|c|}{ Shelling \% } \\
\hline & 2003 & 2004 & Comb. & 2003 & 2004 & Comb. & 2003 & 2004 & Comb. & 2003 & 2004 & Comb. \\
\hline Cultivars (v): & & & & & & & & & & & & \\
\hline 1- Gregory (v1) & 28.7 & 28.8 & 28.7 & 148.4 & 147.4 & 147.9 & 84.9 & 83.0 & 84.0 & 67.47 & 67.59 & 67.53 \\
\hline 2- Giza 6 (v2) & 22.6 & 22.2 & 22.4 & 134.5 & 137.0 & 135.8 & 76.0 & 75.8 & 75.9 & 65.80 & 66.14 & 66.22 \\
\hline F-test & * & $* *$ & $* *$ & $* *$ & $* *$ & ** & ** & ** & ** & ** & ** & ** \\
\hline Various amendments $(\mathrm{s})$ : & & & & & & & & & & & & \\
\hline 1- Wheat straw & $26.9^{\circ}$ & $27.4^{\mathrm{b}}$ & $27.1^{\mathrm{b}}$ & $144.6^{3 \mathrm{~b}}$ & $144.1^{\text {s }}$ & $144.35^{20}$ & $83.9^{6 x}$ & $82.4^{\text {ab }}$ & $83.1^{\star}$ & $67.46^{\mathrm{ab}}$ & $67.95^{3}$ & $67.71^{b}$ \\
\hline 2- Farmyard manure & $29.0^{\mathrm{a}}$ & $28.2^{\mathrm{a}}$ & $28.6^{2}$ & $143.9^{20}$ & $147.1^{\mathrm{a}}$ & $145.5^{a}$ & $85.9^{20}$ & $84.1^{a}$ & $85.0^{\mathrm{ab}}$ & $69.49^{\mathrm{a}}$ & $68.88^{\mathrm{a}}$ & $69.18^{\mathrm{a}}$ \\
\hline 3- Gypsum & $30.5^{\mathrm{a}}$ & $29.7^{\mathrm{a}}$ & $30.1^{\mathrm{s}}$ & $147.3^{\mathrm{a}}$ & $146.4^{\mathrm{a}}$ & $146.8^{2}$ & $86.9^{a}$ & $84.7^{\circ}$ & $85.8^{\mathrm{a}}$ & $67.76^{\infty}$ & $68.40^{3}$ & $68.08^{26}$ \\
\hline 4- Sulphur & $25.8^{\mathrm{b}}$ & $26.0^{b}$ & $25.9^{b}$ & $141.9^{\circ}$ & $142.0^{\circ b}$ & $142.0^{\circ}$ & $82.0^{\circ}$ & $81.3^{\mathrm{ab}}$ & $81.7^{c}$ & $66.80^{\mathrm{b}}$ & $66.83^{\circ}$ & $67.57^{\circ}$ \\
\hline 5- Mineral (NPK) & $25.4^{\circ}$ & $25.8^{\mathrm{b}}$ & $25.6^{\mathrm{b}}$ & $138.0^{c}$ & $138.8^{\mathrm{DC}}$ & $138.4^{c}$ & $77.8^{\circ}$ & $78.0^{\circ}$ & $77.9^{d}$ & $67.07^{\circ}$ & $68.14^{\circ}$ & $67.70^{b}$ \\
\hline 6-Control & $16.2^{c}$ & $15.9^{c}$ & $16.0^{c}$ & $133.1^{\circ}$ & $134.9^{c}$ & $134.0^{d}$ & $66.3^{\mathrm{e}}$ & $66.1^{\mathrm{c}}$ & $66.2^{\mathrm{e}}$ & $61.23^{c}$ & $61.00^{c}$ & $61.114^{\circ}$ \\
\hline$F$ - test & ** & $* *$ & ** & $* *$ & $* *$ & ** & ** & ** & ** & ** & ** & ** \\
\hline Interaction ( $v \times s$ ) & N.S & $*$ & ** & ** & N.S & $* *$ & $* *$ & N.S & $* *$ & N.S & N.S & N.S \\
\hline
\end{tabular}

(*Significant - ** Highly significant - Means having the same letter do not differ significantiy)

Results in Table (5) reflect the presence of genetic differences between the two peanut cultivars. The two-year combined data indicated that Gregory cultivar surpassed the local cultivar, giving evidence that this cultivar could be recommended for the site of experimentation. The various soil amendments varied significantly from each others in both seasons and combined data as to their effect on pod yield, seed 
yield oil \% and oil yield. The highest pod yield and seed yield were obtained when gypsum and farmyard manure were added, singly, in both seasons and combined data. These results are in agreement with those by Hussein et al. (2000).

The lowest values were recorded in the control treatment indicating requirements for certain amendments for a higher yield of peanut in these soils.

Quality characters: Significant differences between the two peanut cultivars for oil yield ( $\mathrm{kg} / \mathrm{fed}$ ) were noticed and insignificant variations were found for oil content (Table 5) in both seasons and combined data. Gregory cultivar gave higher oil yield than Giza 6 in both seasons and combined data as a reflection of higher pod and seed yields. The used soil amendments varied significantly for their effect on oil content and oil yield in both seasons and combined data (Table 5). The wheat straw, farmyard manure, gypsum and control treatments gave the highest and similar oil content. 


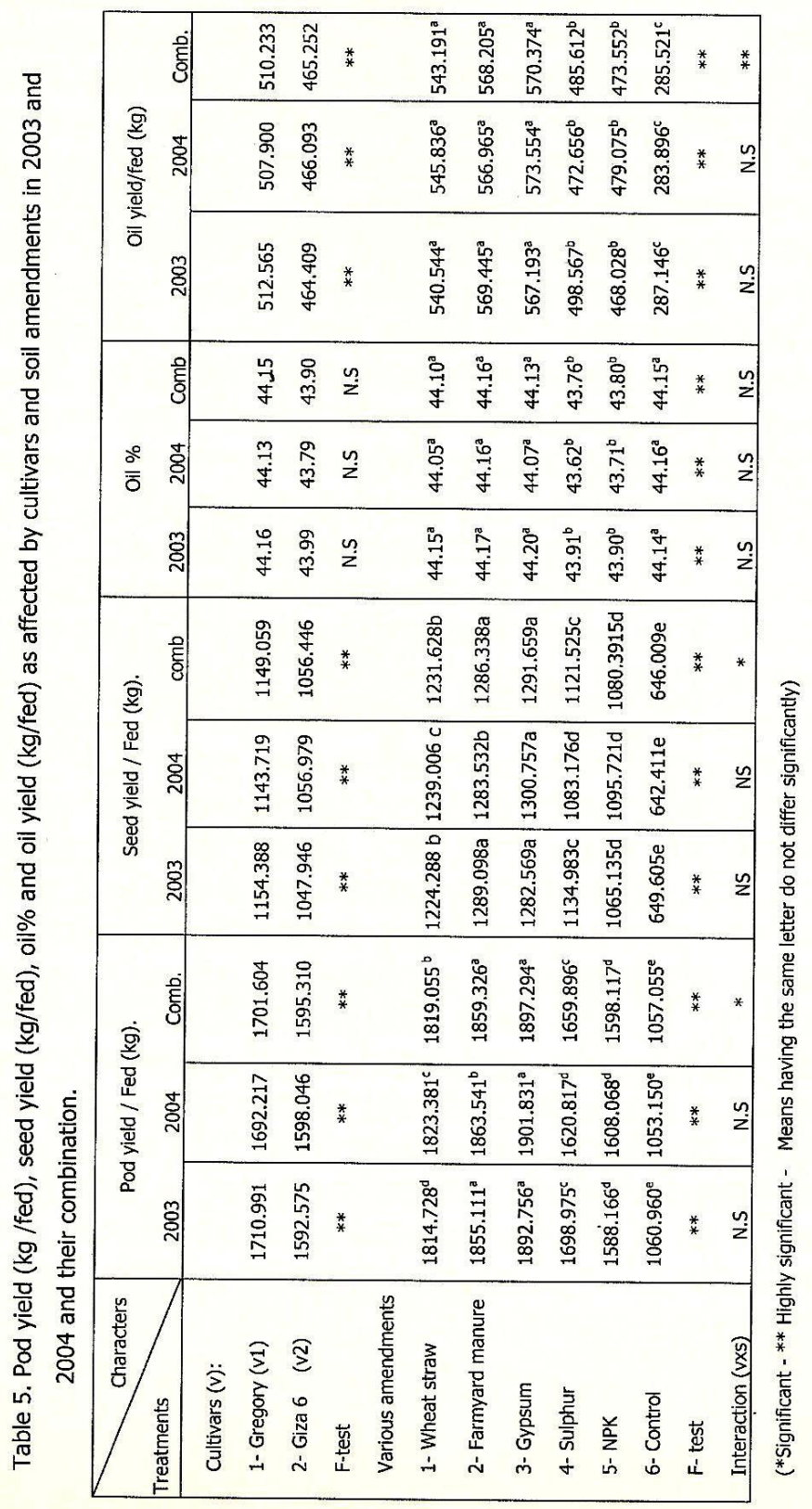



IN PEANUT (ARACHIS HYPOGAEA L)

Meanwhile, applying gypsum or NPK gave the highest oil yield. This may be due to the highest pod yield and consequently the highest oil yield in both seasons and combined data. Interaction effects were only significant for oil yield in the combined data. The control treatment gave the lowest values for the studied characters, indicating the poverty of this soil in various nutrient elements. These results are in accordance with those obtained by Ahmed and Osman (2003).

Interaction effects:

Significant variations were observed for the interaction between peanut cultivars and soil amendments in the combined data for pod, seed and oil yield showing consistency with results of Ahmed and Osman (2003). The highest number of branches/plant, pods weight/plant and seed weight/plant, 100-pod weight, pod yield, seed yield and oil yield were recorded for Gregory cultivar when interacted with gypsum, farmyard manure, wheat straw, sulphur and NPK (Table 6). This shows the importance of those elements to obtain the highest values for the studied characters. This indicates that Gregory interacted with farmyard manure, gypsum and sulphur and gave the highest values for the six characters. These results are in agreement with those obtained by Migawer and Soliman (2001).

\section{Yield analysis:}

Correlation results: Values of simple correlation coefficient $(r)$ for the interrelationships of oil yield, plant height, No. of branches/ plant, pods number/ plant, pod weight/ plant, seed weight/ plant, 100-pod weight, 100-seed weight, shelling percentage, pod yield, seed yield and oil content are given in Table (7). A positive and significant correlation coefficient $(r)$ was observed between oil yield and all the studied characters, except oil content. Also, positive relationship was found between plant height and shelling.

The rest of characters correlated positively with each other indicating that these characters should be considered when selecting the optimum nutrient sources to obtain higher seed and oil yield. Similar results were obtained by Gomaa et a/(1995).

It is of interest to note that oil yield related negatively and insignificantly with all characters, showing that this character share negatively and decrease these characters with various nutrition sources in peanut. These results are in agreement to those of Gomaa et al. (1995). 


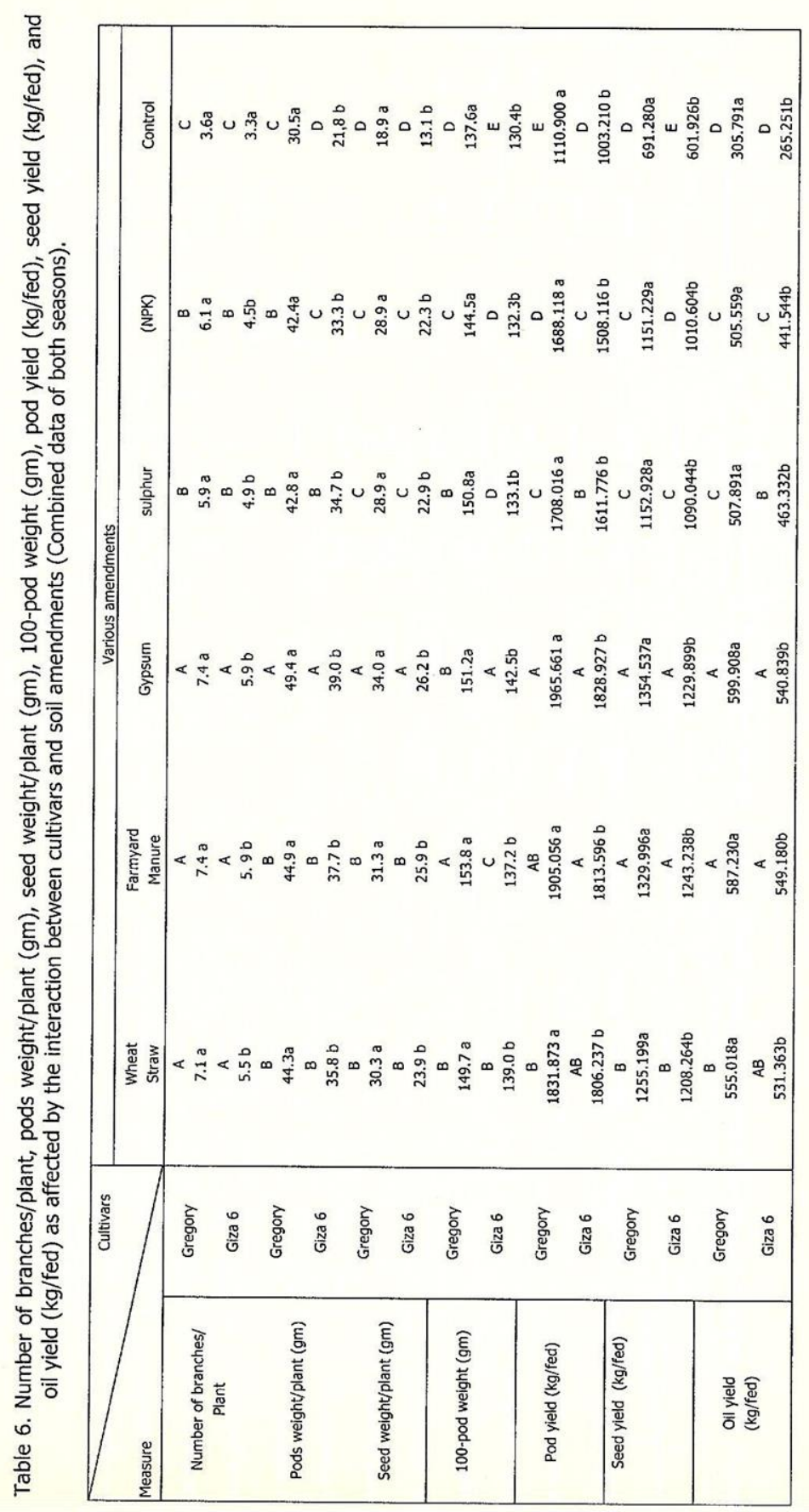




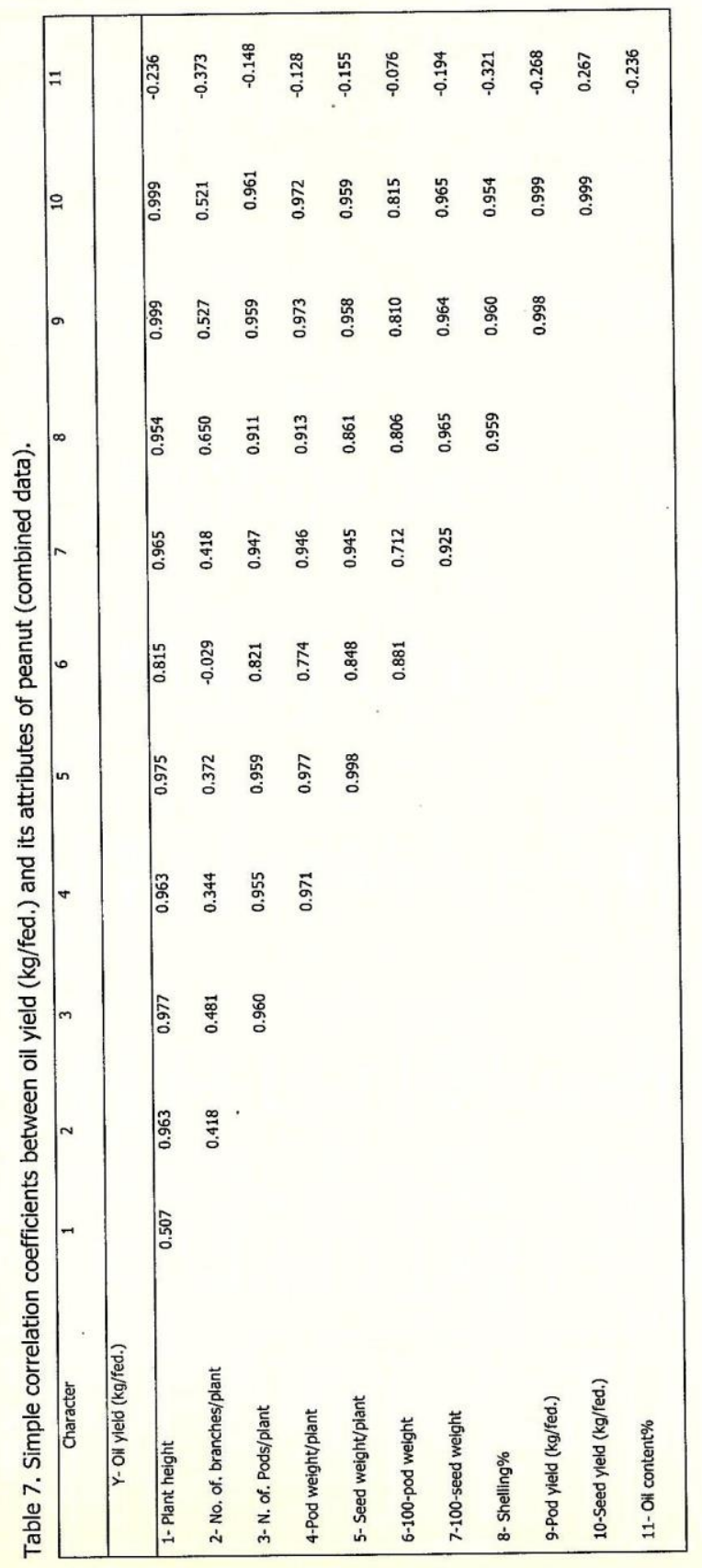




\section{Pathological studies:}

1- Isolation and identification of some soilborne pathogens associated with diseased peanut:

Ten fugal genera and the root-knot nematode, Meloidogyne spp. (M. javanica and $M$. arenaria), were isolated from different disease symptomatic samples of seeds, seedlings and diseased plants (Table 8). These samples included wilted plants, rotted stems, roots and pods that were collected from peanut cultivated in Ismailia. The results indicated that Rhizoctonia solani, Macrophomina phaseolina, Sclerotium rolfsii, Aspergilus niger, Pythium spp. and Meloidogyne spp. were the most serious pathogens on peanut in that area. On the other hand, some of the isolated fungi did not cause disease problems under the conditions of this study. These results are in agreement with those obtained by Helal et al. (1994). The isolation of such peanut pathogens from that area should be considered as a threat to peanut industry in Ismailia. Also, the frequent cultivation of peanut in that area is a considerable factor in the spread and build-up of these pathogens in the soil.

Table 8. The associated fungi or nematodes with soil borne diseases of peanut in Ismailia Agric. Res. Station.

\begin{tabular}{|c|c|c|c|c|c|c|}
\hline $\begin{array}{c}\text { The } \\
\text { isolated pathogen }\end{array}$ & $\begin{array}{c}\text { Seed rot } \\
\text { and } \\
\text { pre-emergence }\end{array}$ & $\begin{array}{c}\text { Post- } \\
\text { emergence } \\
\text { Seedlings and } \\
\text { /or plants. }\end{array}$ & $\begin{array}{l}\text { Stem and /or } \\
\text { collar rot }\end{array}$ & Root rot & Pod rot & $\begin{array}{l}\text { Root and/or } \\
\text { pod galling }\end{array}$ \\
\hline Fusarium moniliformae & + & + & - & - & + & - \\
\hline F. oxysporum & $\because$ & + & + & + & + & - \\
\hline F. solani & + & + & - & + & + & - \\
\hline Macrophomina phaseolina & + & + & + & + & + & - \\
\hline Rhizoctonia solani & + & + & + & + & + & - \\
\hline Sclerotium rolfsili & + & + & + & + & + & - \\
\hline Pythium spp. & + & + & + & + & + & - \\
\hline Aspergillus flavus & - & $\cdot$ & + & - & + & - \\
\hline A. niger & + & + & + & + & + & - \\
\hline Stemphylium spp. & - & - & - & - & + & - \\
\hline Helminthosporium spp. & - & - & - & + & + & - \\
\hline Botrodiplodia spp. & - & - & - & - & + & - \\
\hline Penicillium spp. & - & - & - & - & + & - \\
\hline Meloidogyne spp. & - & - & - & - & - & + \\
\hline
\end{tabular}

+: Present -: Absent.

\section{2- Effect of soil amendments on some peanut diseases:}

\section{A- In greenhouse:}

Results in Table (9) show the effect of the used soil amendments on pre- and post-emergence damping-off, pod rots and yield of Gregory and Giza 6 cvs. in the greenhouse. Data indicate that all the used amendments significantly reduced the incidence of the target diseases and increased the yield compared to the non-treated control in both cultivars. Rhizoctonia solani was the most aggressive in causing preand post- emergence damping-off and pod rots in Gregory and Giza 6 cultivars. 
The highest percentages of pr-, post-emergence damping-off and pod rots were recorded on peanut plants that were sown in the non-amended infested soil. Regarding the used amendments, the highest percentage of pre-emergence dampingoff caused by $R$. solani was found with the farmyard manure at $31.25 \%$ in Gregory and $37.50 \%$ in Giza 6, amended with farmyard manure or NPK. The lowest (6.25\%) was caused by S. rolfsii in both Gregory and Giza 6 amended with Gypsum. The preemergence damping-off was 37.50 and $43.75 \%$ for Gregory and Giza 6, respectively, in the non-amended soil (Table 9).

Regarding the post-emergence damping-off, the highest percentage in Gregory (31.25), or in Giza 6, (43.75), was in plants of soil infested with $R$. solani and amended with farmyard manure or NPK, while the lowest (12.50\%) was observed with either cultivar planted in soil amended with gypsum and infested with $S$. rolfsii. In the non-amended $R$. solani-infested soil (controls), the post-emergence damping-off was $37.50 \%$ in Gregory and $43.75 \%$ in Giza 6 (Table 9).

All the tested fungi were involved in pod rots that ranged from 6.10 to $36.40 \%$ in both Gregory and Giza 6, while it reached $47.80 \%$ in the control plants grown in a non-amended infested soil (Table 9). Rhizoctonia solani caused the highest percentage of rotted pods followed by S. rolfsii and the other tested fungi on Gregory and Giza 6 (Table 9). These results indicated that the tested fungal isolates caused considerable adverse effects on peanut plants at different stages of growth causing losses in peanut production under the applied experimental conditions, soil amendments and peanut cultivars.

Regarding pod yield, all the tested soil amendments increased pod yield compared to the non-amended control. The yield increase varied from an amendment to another with gypsum giving the highest pod yield in both cultivars followed by NPK and other amendments.

With respect to disease incidence, gypsum was the most effective in reducing damping-off and pod rot infections. Infection was significantly decreased with gypsum and wheat straw, while the highest infection percentages were observed with farmyard manure and NPK. Garren (1964) was the first to report the reduction of rotted pods in peanuts as a result of gypsum application. Such an amendment is a good source of calcium which reduces the vulnerability of tissues to attack with parasites. Based on that, the reduction of peanut damped-off plants and rotted pods due to gypsum could be attributed to the role of calcium as an essential factor for biomembranes, the middle lamella and cell wall stability. 


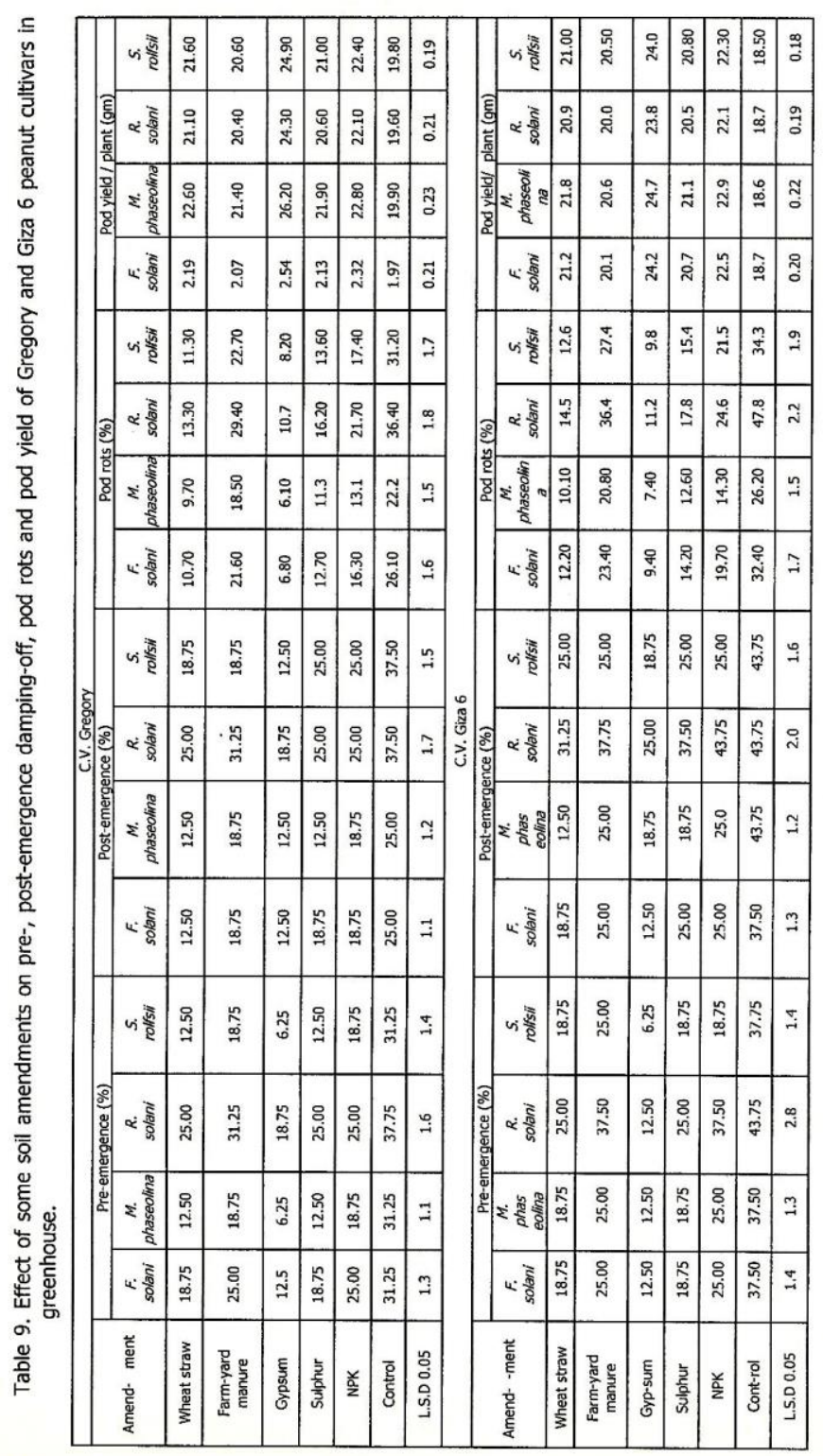


Similar findings were also reported by El-Korashy (2001). Also, El-Deeb et al. (1998) reported that adding wheat and clover straws to soil one week before sowing reduced infection with damping-off and wilt in sesame. This could result from the antifungal effect of delomposed plant straws and/or microorganisms that are antagonistic to the target pathogens.

\section{b- Field experiments:}

The effect of the five soil amendments in reducing pre-, post- emergence damping-off and pod rots under field conditions was similar to that in the greenhouse (Table 10). Also, the cultivar Gregory was less susceptible than Giza 6 in both years.

Gypsum was the most effective in reducing disease incidence, while farmyard manure was the least effective on both cultivars in both years. The lowest percentage of pre-emergence damping-off, (5.4) and the highest, (19.6) were observed in Gregory $\mathrm{cv}$ in soil amended with gypsum and Giza $6 \mathrm{cv}$ in soil amended with farmyard manure, respectively (Table 10). In the control freatment, the pre-emergence damping-off was 20.4 and $25.3 \%$ in Gregory and 22.2 and $27.4 \%$ in Giza 6 in 2003 and 2004, respectively, (Table 10 ).

The percentage of post-emergence damping-off ranged from $6.2 \%$ in the gypsum treatment to $22.4 \%$ in the farmyard manure treatment, in Gregory and from 9.6 to $24.6 \%$ respectively, in the same treatments in Giza 6 in both seasons. In the control treatments, post-emergence infection was 27.4 and $30.6 \%$ in Gregory, while it was 31.2 and $34.4 \%$ in Giza 6 in 2003 and 2004, respectively, (Table 10).

The lowest percentages of pod rots, 4.2 in Gregory and 5.3 in Giza 6, were obtained with the application of gypsum, while the highest percentages of 30.4 in Gregory and 35.1 was in Giza 6, were observed with farmyard manure compared to 39.2 and 41.6 in the controls of Gregory and Giza 6, respectively, (Table 10).

These results could be attributed to the role of calcium in building the cell walls of the plant tissues through the formation of calcium pectate which is more resistant to pectic enzymes which play an impotrant role in pathogenesis. This finding is consistent with that of Chen and Hung (1992) who reported that the addition of gypsum reduced pod rots and improved the appearance and quality of peanut pods and thus its commercial value. 
Table 10. Effect of some soil amendments on pre-, post-emergence damping-off and survival of peanut plants under field conditions in 2003 and 2004.

\begin{tabular}{|c|c|c|c|c|c|c|c|c|c|c|c|c|c|c|c|c|}
\hline \multirow{3}{*}{ Amendm-ent } & \multicolumn{8}{|c|}{ Gregory } & \multicolumn{8}{|c|}{ Giza 6} \\
\hline & \multicolumn{2}{|c|}{$\begin{array}{c}\text { Pre- } \\
\text { emergence } \\
(\%)\end{array}$} & \multicolumn{2}{|c|}{$\begin{array}{c}\text { Post- } \\
\text { emergence } \\
(\%)\end{array}$} & \multicolumn{2}{|c|}{$\begin{array}{c}\text { Survived } \\
\text { plants (\%) }\end{array}$} & \multicolumn{2}{|c|}{$\begin{array}{l}\text { Pod rots } \\
(\%)\end{array}$} & \multicolumn{2}{|c|}{$\begin{array}{c}\text { Pre- } \\
\text { emergence } \\
(\%)\end{array}$} & \multicolumn{2}{|c|}{$\begin{array}{c}\text { Post- } \\
\text { emergence } \\
(\%)\end{array}$} & \multicolumn{2}{|c|}{$\begin{array}{l}\text { Survived } \\
\text { plants (\%) }\end{array}$} & \multicolumn{2}{|c|}{$\begin{array}{l}\text { Pod rots } \\
\text { (\%) }\end{array}$} \\
\hline & 2003 & 2004 & 2003 & 2004 & 2003 & 2004 & 2003 & 2004 & 2003 & 2004 & 2003 & 2004 & 2003 & 2004 & 2003 & 2004 \\
\hline $\begin{array}{l}\text { Wheat } \\
\text { straw }\end{array}$ & 6.0 & 7.1 & 8.3 & 10.2 & 85.7 & 82.7 & 5.3 & 6.4 & 7.3 & 9.2 & 10.2 & 11.8 & 82.5 & 79.0 & 6.7 & 8.6 \\
\hline $\begin{array}{c}\text { Farmyard } \\
\text { manure }\end{array}$ & 15.2 & 16.7 & 22.4 & 23.1 & 62.4 & 60.2 & 30.4 & 29.6 & 17.3 & 19.6 & 24.6 & 22.4 & 58.1 & 58.0 & 33.2 & 35.1 \\
\hline Gypsum & 5.4 & \begin{tabular}{|l|l|}
6.7 &
\end{tabular} & 6.2 & 8.7 & 88.4 & 84.6 & 4.2 & 5.1 & 7.1 & 9.8 & 9.6 & 10.6 & 83.3 & 79.6 & 5.3 & 6.6 \\
\hline Sulphur & 7.9 & 8.7 & \begin{tabular}{|l|}
9.4 \\
\end{tabular} & $\overline{11.2}$ & 83.5 & 80.7 & 6.8 & 7.2 & 8.5 & 10.1 & 11.8 & 13.3 & \begin{tabular}{|l|l|}
79.7 \\
\end{tabular} & 76.8 & 7.8 & 8.4 \\
\hline NPK & \begin{tabular}{|l|}
9.8 \\
\end{tabular} & 12.3 & 11.5 & 14.4 & 78.7 & 73.3 & 18.4 & 21.2 & 11.2 & 14.2 & 15.6 & 16.7 & 73.2 & 69.1 & 21.7 & 23.7 \\
\hline Control & 20.4 & 25.3 & 27.4 & 30.6 & 52.2 & 42.0 & 37.6 & 39.2 & 22.2 & 27.4 & 31.2 & 34.4 & 46.6 & 38.2 & 40.2 & 41.6 \\
\hline L.S.D 0.05 & 0.67 & 0.82 & 1.1 & \begin{tabular}{|l|}
1.2 \\
\end{tabular} & \begin{tabular}{|l|}
2.0 \\
\end{tabular} & 2.1 & 1.3 & 1.4 & 0.88 & 0.97 & 1.2 & \begin{tabular}{|l|}
1.3 \\
\end{tabular} & 1.9 & \begin{tabular}{|l|}
1.4 \\
\end{tabular} & 1.2 & 1.3 \\
\hline
\end{tabular}

On the other hand, the farmyard manure was the least effective in reducing the incidence of pod rots. This may be attributed to that this manure could be a source of any of the target pathogens as it wayhave been ripse or its composition enhanced the activity of some peanut pathogens.

All the used amendments decreased the number of root-knot nematode galls (Table 11) and increased plant height (Table 3) and pod yield (Table 6). Gypsum gave the lowest number of nematode galls/ root, 9-12 and 13-15 in Gregory and Giza 6. On the where hand, farmyard manures application compared to 48 and 52 galls/ root in the non-treated plants in Gregory and Giza 6, respectively, (Table 11).

Table 11. Effect of some soil amendments on number of nematode galls/ plant under field conditions in 2003 and 2004.

\begin{tabular}{|c|c|c|c|c|}
\hline \multirow{2}{*}{ Amendment } & \multicolumn{2}{|c|}{ Gregory } & \multicolumn{2}{c|}{ Giza 6 } \\
\cline { 2 - 5 } & \multicolumn{2}{|c|}{$\begin{array}{c}\text { Number of } \\
\text { nematode galls/root }\end{array}$} & \multicolumn{2}{c|}{$\begin{array}{c}\text { Number of } \\
\text { nematode galls/root }\end{array}$} \\
\cline { 2 - 5 } & 2003 & 2004 & 2003 & 2004 \\
\hline Wheat straw & 12 & 14 & 16 & 17 \\
\hline \multirow{2}{*}{ Farmyard manure } & 35 & 38 & 39 & 35 \\
\hline Gypsum & 9 & 12 & 13 & 15 \\
\hline Sulphur & 19 & 22 & 22 & 23 \\
\hline NPK & 23 & 25 & 28 & 31 \\
\hline Control & 46 & 48 & 49 & 52 \\
\hline L.S.D (0.05) & 2.3 & 2.7 & 2.4 & 2.8 \\
\hline
\end{tabular}


The reduction of nematode galling by those soil amendments could be due to the hardening of the plant cell walls and tissues. Also, some of the used amendments could change the soil pH and accordingly the solubility and availability of some macroand/or micro- elements may be effected and enhance host resistance against rootknot nematode and other peanut pathogens (Abawi and Widmer, 2000). Also, certion amendments could have affected the status of antaganistic organism for the benefit of the host plants.

Pod yield and oil yield in Table (6) were correlated with incidence of the target diseases. Results indicate that the used soil amendments positively affected pod yield and consequently the oil yield. The highest combined pod yield values were 1965.661 and $1828.927 \mathrm{~kg} /$ fed. for Gergory and Giza 6, respectively, were obtained from the gypsum treatment (Tables 6,10 ). The lowest combined pod yield values were 1110.900 and $1003.210 \mathrm{~kg} /$ fed. for Gregory and Giza 6, respectively, when grown in non-amended soil (Tables 6 and 10). Similar trend was observed regarding the oil content as amending soil increased the oil content compared to the non amended one. The increase in pod yield and, subsequently, the oil content could be due to that the used amendments have some nutritive attributes. Also, those amendments reduced infection by peanut pathogens which, in turn, increased the yield and quality of pods. Our results are in consistence with those by Abawi and Widmer (2000).

The foreign cultivar, Gregory, was the best in all characters than the Giza 6, so it is recommended to be cultivated in that area and could be evaluated in other peanut producing areas of Egypt. Also, the promising soil amendments should be considered in the integrated pest management and peanut production enhancement programs.

\section{REFERENCES}

1. Abawi, G. S. and T. L. Widmer. 2000. Impact of soil health management practices on soilborne pathogens, nematodes and root diseases of vegetable crops. Appl. Soil Ecol., 15:537-547.

2. Ahmed, A. A. A. and E. B. A. Osman. 2003. Response of peanut plants grown on a sandy calcareous soil to fertilization with farmyard manure and an organomineral fertilizer prepared from some sugarcane wastes. Assiut. J. Agric. Sci., 34. (6): 337347.

3. Akhtar, M., Z. A. A. Siddiqui and I. Mahmoud. 1998. Management of Meloidogyne incognita in tomato by some- inorganic fertilizers. Nematologia Mediterranea, 26 (1) : 23-25.

4. A. O. A. C. 1980 . Official Methods of Analysis, Association of Official Analytical Chemists, $13^{\text {th }}$ ed. Washington, D. C. 
5. Barnett, H. L. and B. B. Hunter. 1972. Illustrated Genera of imperfect fungi Macmillan Publishing Campany New Yerk.

6. Chen, S. S. and I. W. Hung. 1992. Control of pod rot disease of peanut (Arachis hypogae. L.) by soil amendments. I- Effects on pod rot diseases and yield. J. Agric. and Forestry, 4 ( 2): 77-83.

7. El-Deeb, A. A, S.T. El-Serogy, M. A. Khalil and M. A. El-Korashy. 1998. Effect of some ecological factors on the incidence of damping-off charcoal rot and wilt diseases on sesame and their control. Egypt. J. Appl. Sci., 13 (5): 64-87.

8. El-Korashy, M. A. 2001. Disease incidence and yield of peanut as affected by gypsum amendment, soil moisture and fertilization. Annals Agric. Sci., Moshtohor, 39 (1) : 211-224.

9. Garren, K. H. 1964. Land plaster and soil rot peanut pods in Virginia. PI. Dis. Reptr., 48: 349-352.

10. Gomaa, M. A. A. A. Sarhan and E. A. Abd El-Bary. 1995. Response of peanut to N and $\mathrm{P}$ fertilization under newly reclaimed sandy soil conditions. Egypt. J. Appl. Sci., 10 (4): 292-312.

11. Greish, M. H and S. S. Behairy. 2003. Rotations and preceding winter crops effects on growth, yield and yield components of peanut (Arachis hypogaea.L) in new sandy soils. Proc. $10^{\text {th }}$ National Conf. of Agron. Suez Canal Univ, Fac., Environ., Agric., Sci, El-Arish, Egypt.

12. Helal, A. A, A. H. Metwally, S.A. Khaled and A. A. EL- Deeb. 1994. Evaluation of peanut cultivars, date of sowing and NPK as integrated control measures against soilborne diseases. Zagazig. J. Agric. Res., 21 (4):1151-1162.

13. Hussein, S. M. A. A. M. El-Melegy and M.A. Haikel. 2000. Effect of nitrogen frequency, gypsum application, plant density and their interaction on growth and yield of peanut under drip irrigation system in north Sinai. J. Agric. Sci. Mansoura. Univ., 25 (5): 2427-2438.

14. Migawer, E. A. and M. A. M. Soliman. 2001. Performance of two peanut cultivars and their response to NPK fertilization in newly reclaimed loamy sand soil. J. Agric. Sci., Mansoura Univ., 26 (11): 6653-6667.

15. Omar, A. B.1988. Effect of some nutrients in peanuts. M. Sc. Thesis, Fac. of Agric. Zagazig Univ., Egypt.

16. Snedecor, G. W and W. G. Cochran.1967. Statistical Methods" $6^{\text {th }}$ ed., Iowa State , Univ, Press Ames, Iowa, USA.

17. Waller, R. A. and D. B. Duncan. 1969. A bays rule for symmetric multiple comparison problem. Amer. Sțat. Assoc. J. 12:1485-1503. 


$$
\begin{aligned}
& \text { تأثير بعض الأضافات للتربه على المحصول ومكوناته وصفات الجودة وحدوث الأندابة } \\
& \text { الإصابة بعض أمراض الفول السوداتى لـ } \\
& \text { فوزى محمد اسماعيل '، صلاح محمد عبد المؤمن' } \\
& \text { I . . معهد بحوث المحاصبل الحقلية } \\
& \text { r r معه بحوث امراض النباتات - مركز البحوث الزراعية - الجيزة - مصر }
\end{aligned}
$$

اجريت تجربتان حقليتان فى مزرعة محطة البحوث الزراعية بالاسماعبلية خلا المواسم

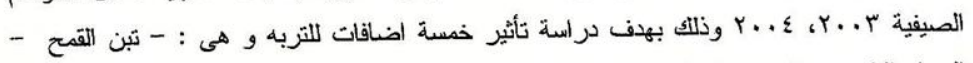

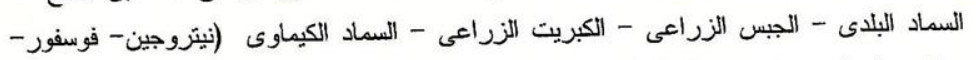

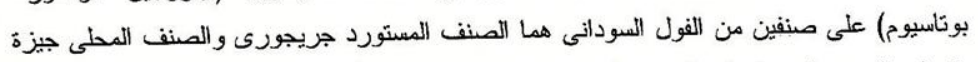
1

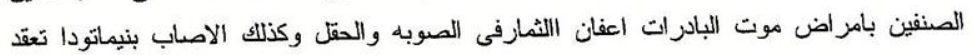

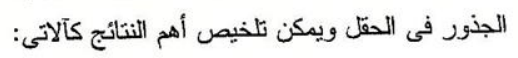

1- تفوق الصنف الاجنبى (جريجورى) معنويا على الصنف المحلى (جيزة 1) فى كل الصفات

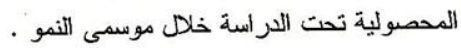

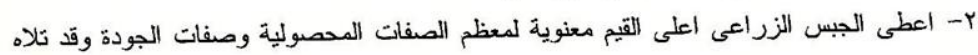

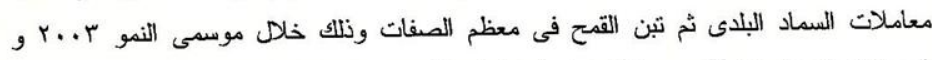

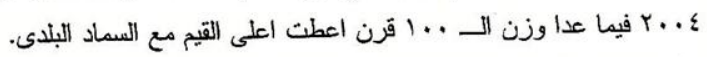

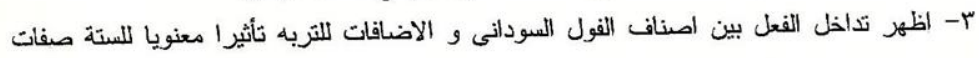

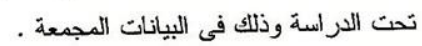

§- .كان هناك ارتباط موجب ومعنوى بين كل الصفات تحت الدر اسة فيما عدا محتوى البذور من

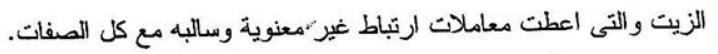

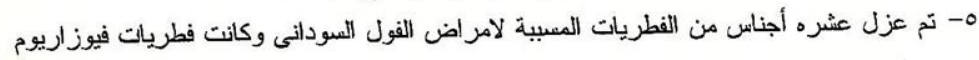

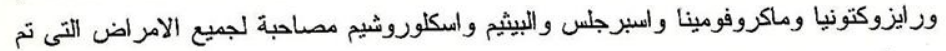

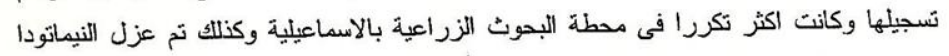

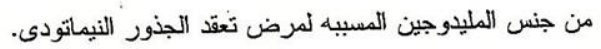

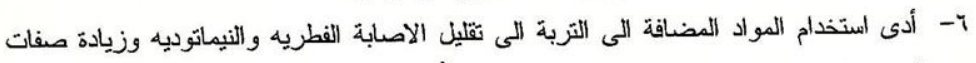

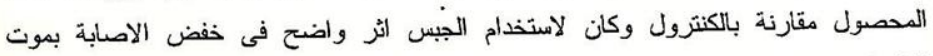

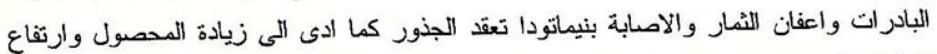

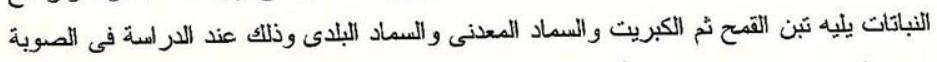

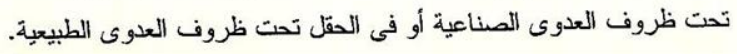


V- أدى إضافة الجبس الزراعى الى احداث اعلا نسبه خفض للاصابة بامز اض موت البادرات

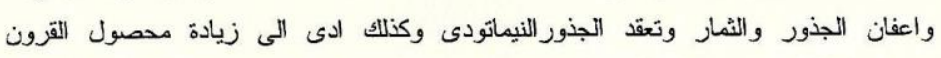

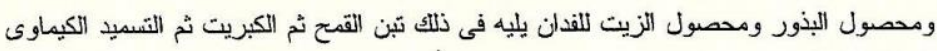
تم السماد البلدى .

وتوصى الاراسة بإضافة الجبس الزراعى الى جانب المعدلات الموصى بها من

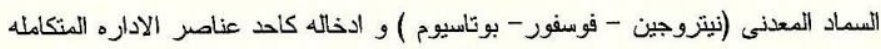

لمحصول الفول المودانى لزيادة محصول القرون ومكوناته وتقليل معد ل الاصابة باعفان

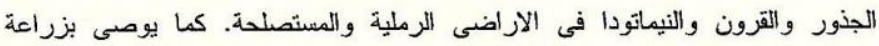

الصنف الاجنبى (جريجورى) فى تلك الاراضى. 